\title{
OPTIMISATION OF A CHROMATIN IMMUNOPRECIPITATION (ChIP) PROTOCOL FOR HISTONE MODIFICATION IN OIL PALM
}

\author{
NORASHIKIN SARPAN*; MEILINA ONG-ABDULLAH* and SIEW-ENG OOI*
}

\begin{abstract}
Chromatin immunoprecipitation (ChIP) is widely used to study protein-DNA interactions, such as histone modifications. A ChIP protocol was established for oil palm tissues by adopting ChIP protocols for other plants and optimising several parameters during chromatin extraction, DNA shearing and immunoprecipitation. ChIP-DNA was evaluated by end-point polymerase chain reaction (PCR) or quantitative polymerase chain reaction ( $($ PCR). The major modification that improved the yield and quality of DNA obtained at the end of the protocol was that the initial steps were conducted in a cold environment. Frozen tissues were also suitable with this chromatin extraction protocol. Satisfactory results were obtained with the optimised protocol, including good quality chromatin and subsequently intact DNA, smaller sizes of sheared chromatin and ChIP-enriched DNA suitable for PCR amplification.
\end{abstract}

Keywords: ChIP, histone modification, epigenetics.

Date received: 9 August 2017; Sent for revision: 16 August 2017; Received in final form: 2 January 2018; Accepted: 2 February 2018.

\section{INTRODUCTION}

The African oil palm (Elaeis guineensis Jacq.) is one of the world's leading food and biofuel crops. It produces two oils - palm oil (PO) from its fruit mesocarp and palm kernel oil (PKO) from the fruit kernel (Murphy, 2014). In Malaysia, the crop was first introduced in the early $20^{\text {th }}$ century and has since become a driving force behind the country's economic growth (Corley and Tinker, 2003). In the past, research on the crop has centred on increasing its palm oil yield (Kushairi et al., 2017; Murphy, 2014). Progress was made, but it was long and arduous. Recently, with the oil palm genome sequenced (Singh et al., 2013a), the genetic contributors to important traits, such as fruit type (Singh et al., 2013b), colour (Singh et al., 2014) and mantleness (Ong-Abdullah et al., 2015), have been tracked down and are expected to hasten breeding progress.

\footnotetext{
Malaysian Palm Oil Board

6 Persiaran Institusi, Bandar Baru Bangi,

43000 Kajang, Selangor, Malaysia.

E-mail: oseng@mpob.gov.my
}

A current trend in plant research is on epigenetics - the study of stable heritable phenotypes despite changes in the chromosomes without DNA sequence alteration (Berger et al., 2009). Epigenetic regulation is known to influence genome-wide gene expression through several mechanisms, including DNA methylation, post-translational modifications of histone proteins and involvement of small RNA (Bennetzen and Zhu, 2011). Cross-talks among these mechanisms lead to changes in the chromatin structure that determines precise spatial and temporal expression of genes depending on diverse environmental cues (Lauria and Rossi, 2011).

Chromatin is built from repeating units, called nucleosomes. Each nucleosome consists of 146base pairs of DNA wrapped around a histone octamer containing two copies of histones $\mathrm{H} 2 \mathrm{~A}$, $\mathrm{H} 2 \mathrm{~B}, \mathrm{H} 3$ and $\mathrm{H} 4$ proteins (Pfluger and Wagner, 2007). It is the modification of these histones that affect chromatin structure. Loose chromatin (euchromatin) marks active transcription while compact chromatin (heterochromatin) is associated with transcriptional repression (Rothbart and Strahl, 2014). Histones are dynamically changed by a vast range of post-translational modifications 
(PTM) at specific amino acid residues in their amino-terminal tails that extend outwards from their nucleosome cores. Chemical marks attached to histones include acetylation, methylation, phosphorylation, ubiquitination, sumoylation and ADP ribosylation (Bannister and Kouzarides, 2011; Dinant et al., 2008). Histone PTM are manifested by multi-subunit complexes that provide 'writer', 'eraser' and 'reader' functions. The former two are involved in the addition and subtraction of histone chemical marks respectively, while the latter binds to specific marks and recruit protein complexes that eventually change the chromatin structure (Schulze et al., 2010).

Chromatin immunoprecipitation (ChIP) assay is a widely used tool to map the localisation of post-translationally modified histones. In ChIP, histone-DNA complexes are immunoprecipitated with PTM-specific antibodies. The specific DNA site bound by the histone is assessed through several ways, including quantitative PCR (ChIP-qPCR), DNA hybridisation array (ChIP-chip) and globalwide sequencing (ChIP-seq) (Park, 2009; Haring et al., 2007; Buck and Lieb, 2004). ChIP has been used in studies on different plants such as Arabidopsis (Roudier et al., 2011), rice (Du et al., 2013), tomato (Ricardi et al., 2010) and maize (West et al., 2014), but there are no reports yet for the oil palm.

Although there are several reported ChIP protocols for use on plants, the protocols vary and none has been reported for oil palm yet. In this study, establishment of a chromatin isolation and ChIP method for oil palm tissues is thus described. The method used in this study was modified and optimised from a protocol used for Arabidopsis (Kaufmann et al., 2010). To our knowledge, this is the first report of a ChIP method for oil palm tissues.

\section{MATERIALS AND METHODS}

\section{Plant Materials and Sample Processing}

Unopened leaflets (spear), young leaflets (cabbage) and female inflorescences at different floral developmental stages (Sarpan et al., 2015) of clonal palms exhibiting normal fruit phenotype at MPOB Research Station, Teluk Intan, Perak, Malaysia were collected, frozen in liquid nitrogen and stored at $-80^{\circ} \mathrm{C}$ until further use. A portion of the unopened leaflets was crosslinked following the instructions in the EpiSeeker ChIP Kit - Plants (Abcam, United Kingdom). Briefly, $1 \mathrm{~g}$ leaf tissue was immersed in $1 \%(\mathrm{v} / \mathrm{v})$ formaldehyde with vacuum infiltration for 10 min. Crosslinking was stopped by the addition of $0.125 \mathrm{M}$ glycine, and vacuum infiltration was applied again for $5 \mathrm{~min}$. The crosslinked tissue was rinsed with water and dried on tissue paper before freezing in liquid nitrogen for storage at $-80^{\circ} \mathrm{C}$.

\section{Chromatin Isolation}

Chromatin isolation was conducted according to Kaufmann et al. (2010), with minor modifications. One gram of crosslinked or non-crosslinked tissues were ground to powder independently in liquid nitrogen and added to $20 \mathrm{ml}$ cold M1 buffer $[0.01 \mathrm{M}$ $\mathrm{NaPO}_{4}$ (pH 7), $0.1 \mathrm{M} \mathrm{NaCl}, 12.8 \%$ (v/v) 2-methyl-2,4 pentanediol, $\quad 0.08 \% \quad(\mathrm{v} / \mathrm{v}) \quad \beta$-mercaptoethanol] and supplemented with half tablet of Complete Protease Inhibitor Cocktail (Roche, Switzerland). The mixture was incubated at $4^{\circ} \mathrm{C}$ for 15 min with gentle shaking (90 rpm) and filtered through four layers of Miracloth (Calbiochem, Merck, US). An additional $5 \mathrm{ml} \mathrm{M} 1$ buffer was poured through the filter to flush out any residual filtrate. The filtrate was then centrifuged at $1900 \times \mathrm{g}$ at $4^{\circ} \mathrm{C}$ for $20 \mathrm{~min}$. The supernatant was discarded and the pellet was resuspended in $1 \mathrm{ml}$ cold $\mathrm{M} 2$ buffer $\left[0.01 \mathrm{M} \mathrm{NaPO}_{4}\right.$ ( $\mathrm{pH} 7), 0.1 \mathrm{M} \mathrm{NaCl}, 12.8 \%$ (v/v) 2-methyl-2,4 pentanediol, $0.01 \mathrm{M} \mathrm{MgCl}_{2}, 0.5 \%$ (v/v) Triton $\mathrm{x}-100$, $0.08 \%(\mathrm{v} / \mathrm{v}) \quad \beta$-mercaptoethanol and $500 \mu \mathrm{l} 2 \mathrm{X}$ concentrated Complete Protease Inhibitor Cocktail (Roche, Switzerland)]. The mixture was centrifuged at $18000 \times \mathrm{g}$ at $4^{\circ} \mathrm{C}$ for $10 \mathrm{~min}$. The supernatant was discarded and the pellet was resuspended in $600 \mu 1$ cold M3 buffer [0.01 $\mathrm{M} \mathrm{NaPO}_{4}$ (pH 7), $0.1 \mathrm{M}$ $\mathrm{NaCl}, 0.08 \%$ (v/v) $\beta$-mercaptoethanol and $300 \mu 12 \mathrm{X}$ concentrated Complete Protease Inhibitor Cocktail (Roche, Switzerland)]. The mixture was centrifuged at $21000 \mathrm{xg}$ at $4^{\circ} \mathrm{C}$ for $20 \mathrm{~min}$. The supernatant was discarded and the pellet was resuspended in $400 \mu \mathrm{l}$ Sonic buffer [0.01 $\mathrm{M} \mathrm{NaPO}_{4}$ ( $\mathrm{pH} 7$ ), $0.1 \mathrm{M} \mathrm{NaCl}, 0.5 \%$ $(\mathrm{w} / \mathrm{v}) \mathrm{N}$-Laurylsarcosine sodium] supplemented with $100 \mu 12 X$ concentrated Complete Protease Inhibitor Cocktail (Roche, Switzerland).

\section{Chromatin Shearing}

Two types of sonicator were used for shearing: a Q700 sonicator (QSonica, USA) and a M220 Covaris focused-ultrasonicator (Covaris, USA). Based on the manufacturer's instructions, the former was operated at $30 \%$ amplitude using cycles of $1 \mathrm{~min}$ pulses with 1 min rest in between, and optimised by varying the number of sonication cycles. The latter was optimised to produce fragments of 200 bp to $500 \mathrm{bp}$ in size, averaging at $300 \mathrm{bp}$, with the following parameters: 5\% duty factor, 200 cycles/ burst, $4^{\circ} \mathrm{C}$ waterbath temperature and at various duration from 4 to 25 min shearing time using a screw cap microTUBE $(50 \mu 1)$ in a XT holder. The sheared chromatin was centrifuged at $14000 \mathrm{rpm}$ at $4^{\circ} \mathrm{C}$ for $10 \mathrm{~min}$ to remove insoluble cellular debris. A small portion of the sheared chromatin was used for reverse crosslinking following Kaufmann et al. (2010) with minor modifications. The sheared chromatin was firstly treated with $0.5 \mathrm{mg} \mathrm{ml}^{-1}$ Proteinase-K at $37^{\circ} \mathrm{C}$ overnight. The dissociation of histones from 
its DNA was continued by adding another $0.5 \mathrm{mg}$ $\mathrm{ml}^{-1}$ Proteinase-K and further incubation at $65^{\circ} \mathrm{C}$ for at least $6 \mathrm{hr}$. The mixture was then purified by an equal volume of chloroform:isoamyl alcohol (24:1) extraction. The aqueous phase was transferred into a new tube and the DNA was precipitated with 2.5 volumes of absolute ethanol, 0.1 volume of $3 \mathrm{M}$ $\mathrm{NaOAc}(\mathrm{pH} 5.2)$ and $1 \mu \mathrm{l}$ of $20 \mathrm{mg} \mathrm{ml}^{-1}$ glycogen overnight at $-20^{\circ} \mathrm{C}$. The mixture was centrifuged at $12000 \mathrm{rpm}$ at $4^{\circ} \mathrm{C}$ for $20 \mathrm{~min}$ and the DNA pellet was dissolved in water. Subsequently, shearing efficiency was assessed by gel electrophoresis of the respective DNA.

\section{Chromatin Immunoprecipitation (ChIP)}

ChIP was conducted using the following ChIP-validated antibodies [anti-H3K9me2 (ab1220); anti-H3K4me3 (ab12209); anti-H3K27me3 (ab6002), (Abcam, UK)]. ChIP was either conducted according to Kaufmann et al. (2010) or a commercially available ChIP kit. Using the protocol from Kaufmann et al. (2010), chromatin immunoprecipitation was conducted immediately after chromatin isolation and shearing. Briefly, the sheared chromatin was subjected to pre-clearing to reduce undesirable background during ChIP. This was followed by incubation with the specific antibody and isolation of the antibody-protein/ DNA complexes using protein-A agarose beads. After the immunoprecipitation step, DNA was isolated by reverse crosslinking and purified. Alternatively, ChIP was also conducted using a commercial kit, EpiSeeker ChIP Kit - Plants (Abcam, UK), according to the manufacturer's instructions, with minor modifications. Firstly, a small portion of diluted sheared chromatin (designated as input DNA) was set aside as control, which was not immunoprecipitated. ChIP reactions were carried out by incubating the antibody with diluted sheared chromatin at $4^{\circ} \mathrm{C}$ overnight (instead of at room temperature for 60 - 90 min). A mock ChIP using mouse IgG (provided in the kit) was also performed. After several washes, the ChIP products and input DNA were reverse crosslinked and purified using QIAquick PCR Cleanup Kit (Qiagen, Germany).

\section{Evaluation of ChIP Enrichment by Polymerase Chain Reaction (PCR)}

After reverse crosslinking, PCR was conducted to evaluate the immunoprecipitated DNA. Several primers for possible target regions with histone modifications were designed (Table 1). Primers targeting the Tos17 orthologue locus (Acc. No. KF142646) in oil palm at two locations were synthesised. Tos17 is a copia-like retrotransposon associated with H3K9 dimethylation (Ding et al., 2007). In addition, primers were also designed to target the putative Elaeis guineensis MADS-box transcription factor 2 (Acc. No. NC_025994.1 at nucleotides $6,794,871$ to $6,794,981)$.

The PCR mixture in a total volume of $20 \mu \mathrm{l}$ contained $2 \mu \mathrm{l}$ DNA, 1X MPOB PCR buffer, $0.2 \mathrm{mM}$ dNTP mix (Promega, USA), $0.5 \mu \mathrm{M}$ forward primer, $0.5 \mu \mathrm{M}$ reverse primer and 2.5 U MPOB mTaq DNA polymerase (MPOB TS No.19) (Ong-Abdullah et al., 2007). PCR was conducted as follows: $2 \mathrm{~min}$ at $95^{\circ} \mathrm{C}$; 35 cycles of $95^{\circ} \mathrm{C}$ for $30 \mathrm{~s}, 56^{\circ} \mathrm{C}$ for $30 \mathrm{~s}$ and $72^{\circ} \mathrm{C}$ for $30 \mathrm{~s}$; and a final $2 \mathrm{~min}$ at $72^{\circ} \mathrm{C}$. The PCR products were electrophoresed in a $2 \%(\mathrm{w} / \mathrm{v})$ agarose gel and stained with ethidium bromide. Gel images were photographed using the VersaDoc 4000 Imaging System (Biorad, USA).

Evaluation of DNA obtained from ChIP was alternatively carried out using quantitative PCR (qPCR) as this allowed quantification of specific histone modification regions (Lin et al., 2012). Real time PCR was performed on the Mastercycler EP Realplex 4X (Eppendorf, Germany) with the following parameters: 1X SYBR Premix ExTaq (Takara, Japan), $0.2 \mu \mathrm{M}$ forward primer, $0.2 \mu \mathrm{M}$ reverse primer and $2 \mu \mathrm{l}$ input- or ChIP-DNA in 10 $\mu$ l total volume. The PCR program used was: $30 \mathrm{~s}$ at $95^{\circ} \mathrm{C} ; 40$ cycles of $95^{\circ} \mathrm{C}, 3 \mathrm{~s}$ and $60^{\circ} \mathrm{C}, 20 \mathrm{~s}$. ChIPqPCR analysis was done following the percent of input method. (Haring et al., 2007), i.e., the following formula was applied: (1) adjusted input to $100 \%=$ Ct input - $\log _{2} \mathrm{DF}$ (DF; dilution factor); (2) $\Delta \mathrm{Ct}$ (normalised ChIP) $=$ adjusted input $-\mathrm{Ct}$ ChIP; (3) $\%$ input $=2^{\wedge}[\Delta \mathrm{Ct}$ (normalised ChIP) $] \times 100 . \mathrm{Ct}$ is defined as the cycle when the sample fluorescence exceeds a chosen threshold above the background fluorescence (Adams, 2006). Student's t-test was used to analyse the difference between active and repressive histone marks.

\section{RESULTS AND DISCUSSION}

ChIP has been widely used in the past decade to determine the in vivo locations of binding sites for various histone and non-histone proteins (Landt et al., 2012). Knowledge on such locations is vital to understand the many cellular functions that mediate numerous biological processes. Briefly, a typical ChIP procedure consists of crosslinking the proteins to DNA, isolation and sonication of chromatin, immunoprecipitation of chromatin with antibodies targeted to the proteins of interest, crosslinking reversal of protein/DNA complexes and, finally, PCR amplification with specific primers or other methods to assess the presence of target DNA sequences in the immunoprecipitated fractions. Many variations of the basic ChIP protocol for plants have been published (Haring et al., 2007; Bowler et al., 2004). In this study, a ChIP protocol from Kaufmann et al. 
TABLE 1. PRIMER SEQUENCES FOR POLYMERASE CHAIN REACTION (PCR) AND QUANTITATIVE POLYMERASE CHAIN REACTION (qPCR) EXPERIMENTS

\begin{tabular}{cllc}
\hline Primer ID & Target region & Forward & \multicolumn{1}{c}{ Reverse } \\
\hline A & Tos17 & 5' TCCAGGGGGTTGTTCTACAT 3' & 5' AAGAAATAATGTTTGGACCT 3' \\
B & Tos17 & 5' GTAGTTCCTTGGTGTACTTGCT 3' & 5' AACAACCCCCTGGATTTGA 3' \\
C & MADS-box & 5' CAGTGGCGGGGTCTGAAC 3' & 5'AGGATGGATGAAGGCGGTGA 3' \\
& transcription & & \\
& factor 2 & & \\
\hline
\end{tabular}

(2010) was adopted for oil palm tissues with several optimisations and incorporation of a commercial immunoprecipitation kit.

\section{Chromatin Isolation Protocol Modifications Improved Yield and Quality of DNA}

Optimisation of chromatin isolation procedures was firstly conducted on unopened leaflets. However, a direct adaptation of the method by Kaufmann et al. (2010) did not yield intact DNA after the reverse crosslinking step (Figure 1A). Therefore, several changes to the protocol were made, including (1) incubating the sample-extraction buffer mixture in a cold room $\left(4^{\circ} \mathrm{C}\right)$ with gentle shaking; (2) filtering through two additional layers of Miracloth; (3) filtering the sample-buffer mixture in a cold room $\left(4^{\circ} \mathrm{C}\right) ;(4)$ increasing the centrifugation speed from $1000 \times \mathrm{g}$ to $18000 \times \mathrm{g}-21000 \mathrm{x}$ g. The quality and yield of chromatin isolated with the modified protocol was similar to the chromatin extracted using a commercial kit (Figures $1 B$ and $1 C$ ). This modified extraction protocol would enable cost savings in chemicals and reagents compared to a commercial chromatin extraction kit. The modified protocol also worked well on young leaves and female inflorescences (Figure 2) whereby intact DNA was obtained after reverse crosslinking. DNA yields were also adequate with lower impurities (Table 2). However, $A_{260} / A_{230}$ values were lower than the recommended range of 1.8-2.2 (Desjardins and Conklin, 2010) as oil palm tissues are generally rich in polysaccharides. DNA of such quality can still be used for PCR amplification as there is no consensus on the acceptable lower limit of this ratio. Besides, success in amplification of DNA-extract does not
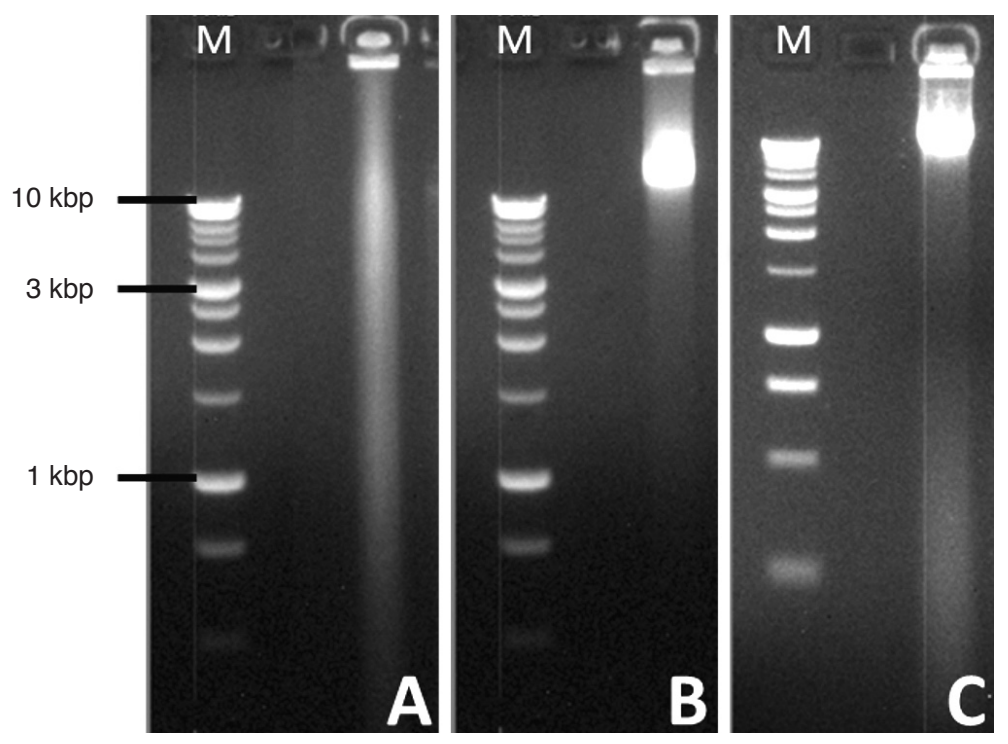

Figure 1. DNA obtained after reverse crosslinking of chromatin isolated using different methods. (A) Kaufmann et al. (2010) protocol, (B) commercial kit (EpiSeeker ChIP Kit - Plants, (C) modified Kaufmann et al. (2010) protocol. M: 1 kb DNA ladder (Promega, USA).

TABLE 2. PURITY AND YIELD OF DNA OBTAINED AFTER REVERSE CROSSLINKING OF CHROMATIN

\begin{tabular}{lccc}
\hline Sample & $\mathbf{A}_{\mathbf{2 6 0}} / \mathbf{A}_{\mathbf{2 8 0}}$ & $\mathbf{A}_{\mathbf{2 6 0}} / \mathbf{A}_{\mathbf{2 3 0}}$ & Concentration(ng $\left.\boldsymbol{\mu l}^{\mathbf{- 1}}\right)$ \\
\hline Young leaf (cabbage) & 1.821 & 1.291 & 152.636 \\
Stage 1 female inflorescence & 1.835 & 1.038 & 111.693 \\
Stage 2 female inflorescence & 1.816 & 1.002 & 95.774 \\
Stage 4 female inflorescence & 1.719 & 1.027 & 200.244 \\
Stage 5 female inflorescence & 1.928 & 1.173 & 161.301 \\
\hline
\end{tabular}


always correlate with the OD (optical density) ratio (Lucena-Aguilar et al., 2016). Overall, the modified protocol works with various types of oil palm tissues.

\section{Chromatin Yields from Frozen Tissues Similar to Yields from Formaldehyde-fixed Tissues}

Most chromatin isolation procedures involve tissue fixation or crosslinking with formaldehyde. However, tissues for ChIP in histone modification studies may not require crosslinking due to the tight association of histone-DNA complexes (Liu et al., 2010). Thus, frozen tissues for chromatin isolation were tested. Tissue samples that were not crosslinked gave similar DNA yields to crosslinked tissues (Figure 3). Crosslinking of frozen tissues at different durations was also conducted. However, degraded DNA was obtained for all durations tested (Figure 4). This suggested that fixation of frozen oil palm tissues is not suitable as thawing of tissues during fixation probably led to DNA degradation. The use of frozen samples is thus limited to ChIP for histones and will not be appropriate for transcription factor studies (Wells and Farnham, 2002). Moreover, the use of frozen samples rather than fresh samples would ease oil palm sampling in the field due to the often long distance and duration taken from the field to the laboratory.

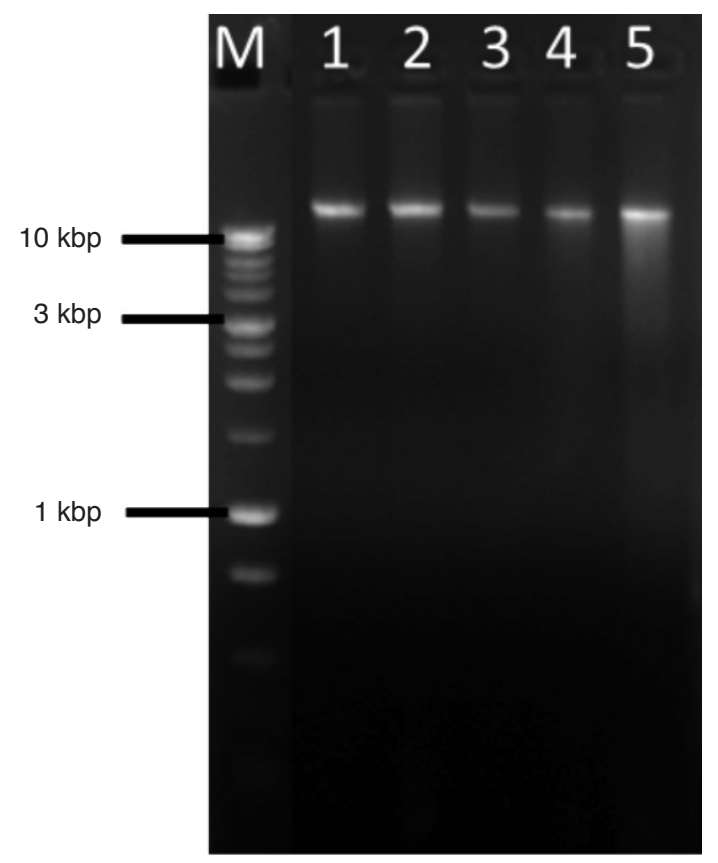

Figure 2. Oil palm chromatin from various types of tissues. DNA obtained after reverse crosslinking of chromatin isolated from, 1: young leaf (cabbage), female inflorescence at floral development, 2: stage 1, 3: stage 2, 4: stage 4, 5: stage 5. M: $1 \mathrm{~kb}$ DNA ladder (Promega, USA).
Type of Sonicator is Crucial for Reproducible Chromatin Shearing

Mechanical shearing of chromatin by sonication greatly depends on the instrument used. The performance of a M220 Covaris focusedultrasonicator (Covaris, USA) and a Q700 sonicator (QSonica, USA) was compared. Optimisation of shearing parameters was done to obtain $200 \mathrm{bp}-300$ $\mathrm{bp}$ fragments as this size range recommended for the generation of high-resolution histone modification maps (Mokry et al., 2010). The M220 which operates
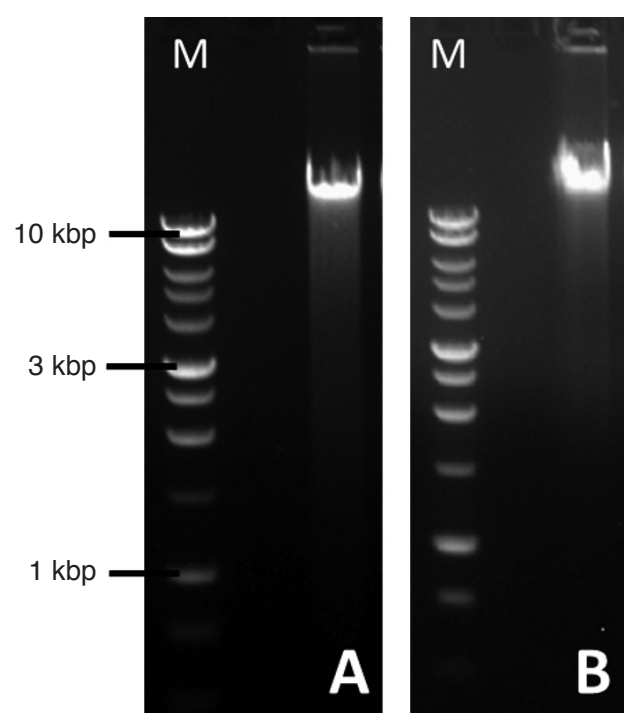

Figure 3. DNA obtained from reverse crosslinking of chromatin from freshly fixed and frozen tissues. (A) Sampled tissues fixed in formaldehyde fixative prior to freezing in liquid nitrogen and $-80^{\circ} \mathrm{C}$ storage, (B) Sampled tissues immediately frozen in liquid nitrogen and stored at $-80^{\circ} \mathrm{C}$. M: $1 \mathrm{~kb}$ DNA ladder (Promega, USA).

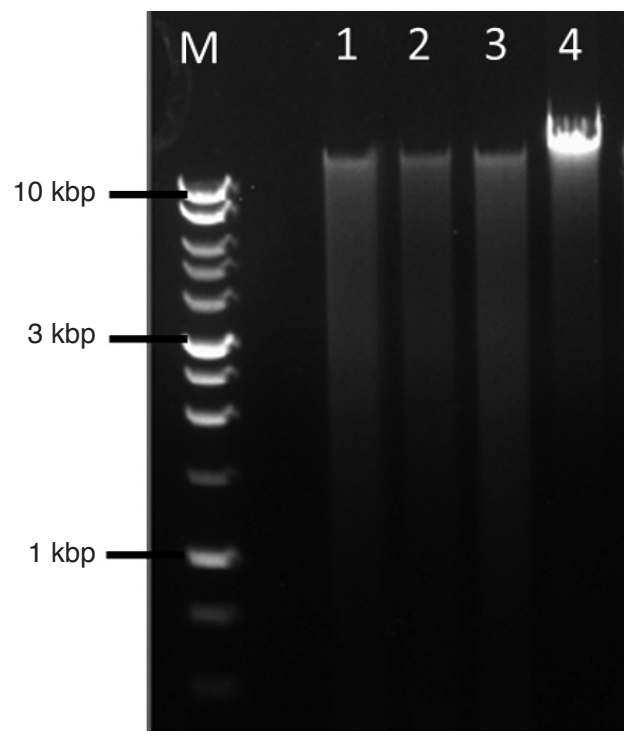

Figure 4. Various crosslinking duration of frozen tissues in formaldehyde fixative with vacuum infiltration. DNA from chromatin of frozen tissues were crosslinked by vacuum infiltration in fixative for, 1: $10 \mathrm{~min}$, 2: $15 \mathrm{~min}$, 3: $20 \mathrm{~min}$, 4: non-crosslinked, frozen tissues. M: $1 \mathrm{~kb}$ DNA ladder (Promega, USA). 
at $500 \mathrm{kHz}$ (ultrasonic range), produced a more compact DNA smear of smaller fragments than the Q700 after optimisation of shearing times (Figure $5 \mathrm{~A})$. The latter which operates at $20 \mathrm{kHz}$, was not able to produce such small fragments, even with extended shearing times. The DNA smear obtained by shearing for $20 \mathrm{~min}$ was similar to the smear obtained by shearing for $15 \mathrm{~min}$, indicating there was no improvement even with an increase in the shearing duration (Figure 5B). Moreover, the size range of sheared DNA obtained using the cup-horn Q700 sonicator was broad compared to the size range obtained using the M220 sonicator. The use of sheared DNA with narrow size ranges and small mean lengths is recommended for downstream experiments such as next generation sequencing.

\section{ChIP Yields and Purity was Suitable for PCR Amplification}

ChIP products obtained with the modified protocol were assessed using PCR with specific primers. For this, primers were designed to a Tos17 orthologous sequence in oil palm, as Tos17 is a copia-like retrotransposon associated with $\mathrm{H} 3 \mathrm{~K} 9$ dimethylation (Ding et al., 2007). In oil palm, this region is associated to a truncated and disrupted $D E F 1$ gene and is located near two retrotransposons. Using the H3K9me2-ChIP products obtained with the modified Kaufmann et al. (2010) protocol, Tos17amplified products of expected sizes were generated from the input chromatin and ChIP replicates (Figure 6). Another option is to use quantitative real time PCR (qPCR) to quantify target regions from ChIPenriched DNA compared to input chromatin as end point PCR only provides a direct assessment of target regions associated with the protein of interest.

H3K4me3-ChIP and H3K27me3-ChIP products obtained using the commercial EpiSeeker - Plant ChIP kit were thus tested using qPCR with primers targeted to an oil palm MADS-box gene. This gene was of interest in a concurrent study to investigate epigenetic changes associated with mantling and floral development (unpublished data). The qPCR results here showed that the MADS-box transcription factor gene might be associated
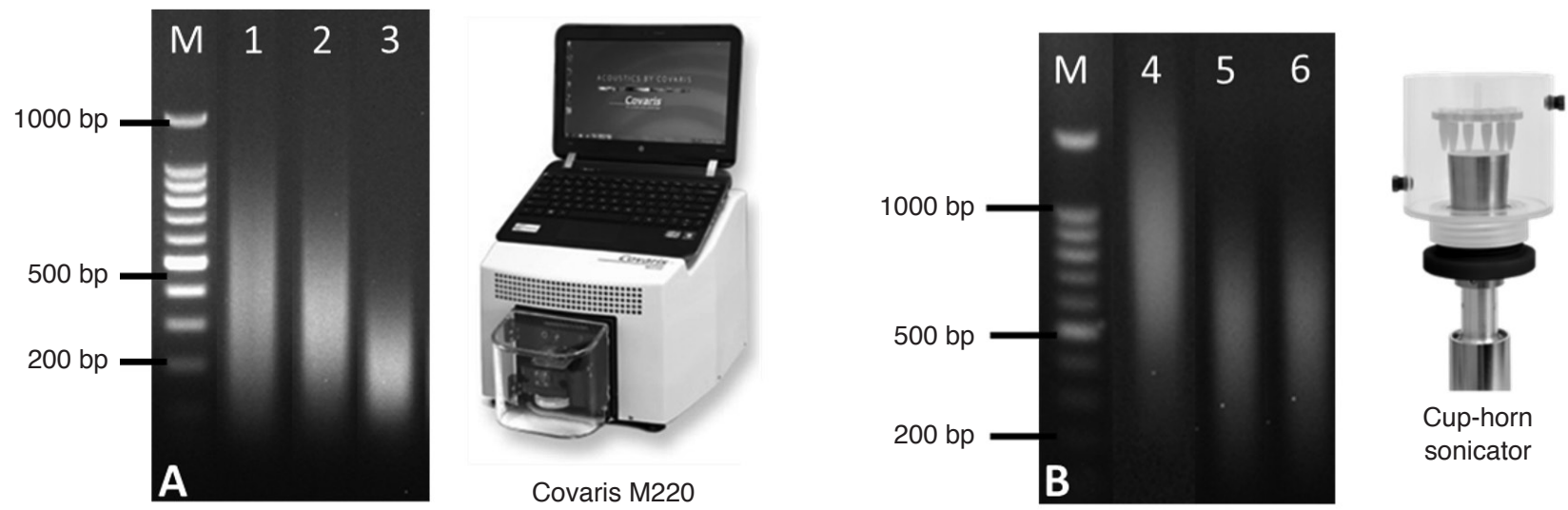

Figure 5. Size ranges of fragmented chromatin generated by Covaris M220 and Q700 cup-horn sonicator at various sonication times. Chromatin was sheared for a total of 1: $4 \mathrm{~min}, 2: 8 \mathrm{~min}$ and 3: 25 min using Covaris M220; and for, 4: $10 \mathrm{~min}, 5: 15 \mathrm{~min}$ and 6: 20 min using the Q700 cup-horn sonicator. Shearing cycle protocols are as described in Materials and Methods. M: 100 bp DNA ladder (Promega, USA).

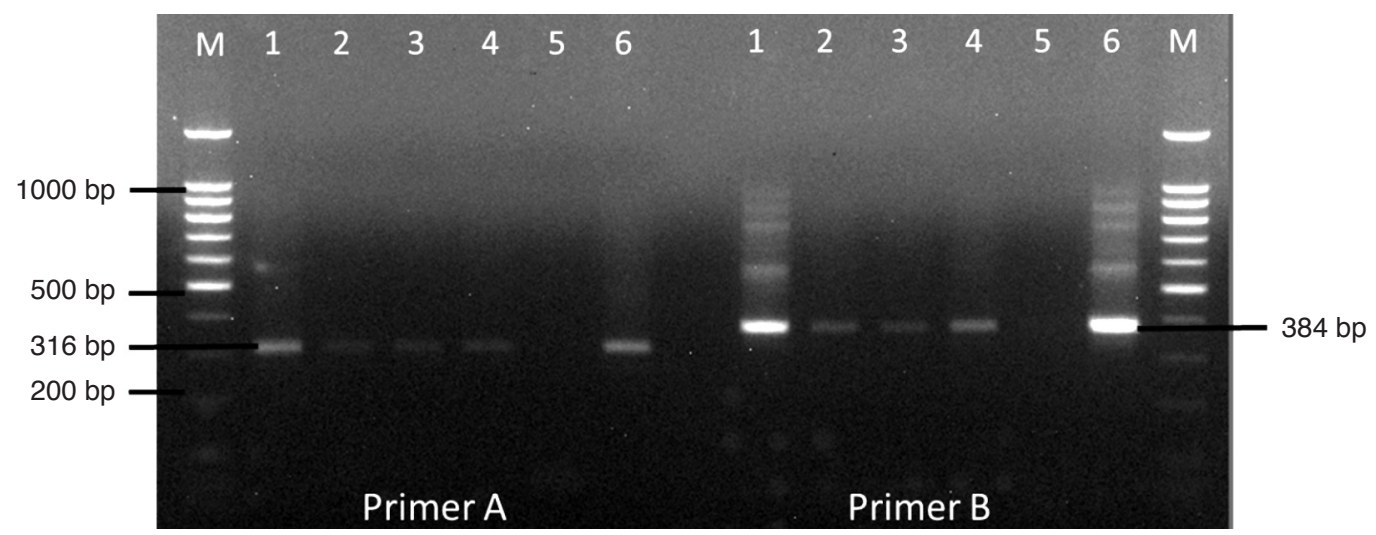

Figure 6. Amplified Tos17 polymerase chain reaction (PCR) products from H3K9me2-ChIP (chromatin immunoreciptation) product and input chromatin with two primer sets, A and B. 1: input chromatin (non-immunoprecipitated), $2: 1^{\text {st }}$ ChIP replicate, $3: 2^{\text {nd }}$ ChIP replicate, $4: 3^{\text {rd }}$ ChIP replicate, 5: PCR negative control, 6: PCR positive control from genomic DNA template. M: 100 bp DNA ladder (Promega, USA). 


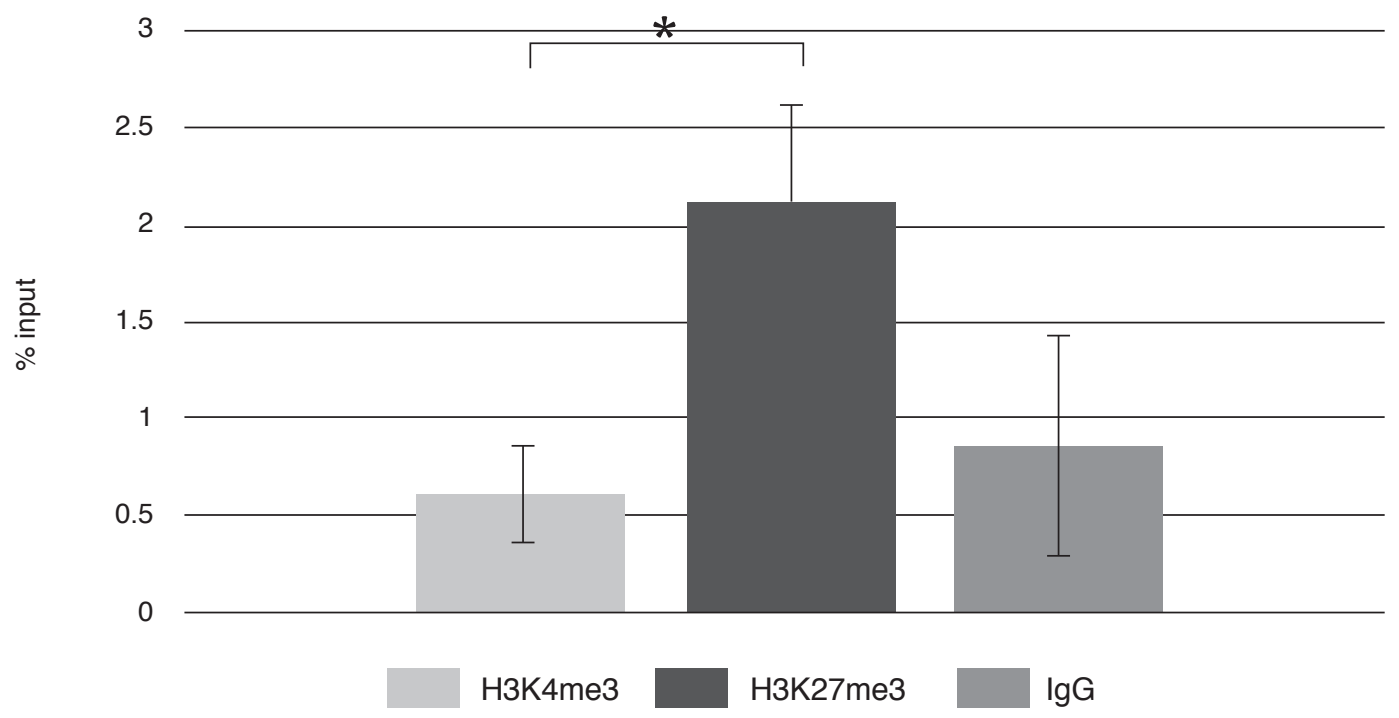

Figure 7. Quantitative polymerase chain reaction ( $q P C R)$ analysis of a MADS-box transcription factor 2 gene on ChIP-DNA. Chromatin samples were immunoprecipitated with anti-H3K4me3, anti-H3K27me3 and IgG (non-specific background control). All results were normalised to Ct levels from input chromatin. Error bars indicate standard deviation ( $n=2) .{ }^{*}$ Significant difference between active (H3K4me3) and repressive (H3K27me3) marks $(p<0.05)$

with higher H3K27me3 modifications as their amplified levels were higher than that of the nonspecific background (IgG) (Figure 7). The levels of this repressive H3K27me3 mark was significantly different from the active $(\mathrm{H} 3 \mathrm{~K} 4 \mathrm{me} 3)$ mark $(\mathrm{p}<0.05)$. The ChIP step conducted using the commercial kit provided sufficient yields of ChIP products for PCR amplification, with an added advantage of assay flexibility for high-throughput applications compared to ChIP steps in the modified Kaufmann et al. (2010) protocol which was relatively more tedious. Overall, the results demonstrated that PCR amplification was successful for all ChIP products obtained through modified Kaufmann et al. (2010) protocol or the commercial ChIP kit, indicating that the ChIP yields are sufficient for PCR amplification experiments.

\section{CONCLUSION}

In summary, a good ChIP protocol may be defined as one applicable for a broad variety of plant tissues, yielding high quality DNA in satisfactory amounts and generating the least false signals on amplification (Saleh et al., 2008). The modified ChIP protocol described here provided satisfactory results with oil palm tissues. In future, comprehensive investigation of global histone modifications can be carried out by combining this protocol with highthroughput sequencing technologies.

\section{ACKNOWLEDGEMENT}

We are grateful to the Director-General of MPOB for permission to publish this study. We thank Roslan Ngadio, Feshah Ishak, Azizah Mokri, Shamshul Bahri Abdul Manap, Rosna Angsor, Rajini Mohamed, Nuraziyan Azimi, Masniyana Jamil and Mohd. Amin Shaharoddin Samat from the Biomarker Discovery Group, Advanced Biotechnology and Breeding Centre (ABBC), MPOB, for their invaluable technical support. Our appreciation also goes to Zamzuri Ishak of the Clonal Propagation Group, ABBC, MPOB for the clonal palms used in this study. This study was financially supported by MPOB.

\section{REFERENCES}

ADAMS, P S (2006). Data analysis and reporting. Real-time PCR (Dorak, M T ed.). Taylor \& Francis Group, United Kingdom. p. 39-62.

BANNISTER, A J and KOUZARIDES, T (2011). Regulation of chromatin by histone modifications. Cell Res., 21(3): 381-395.

BENNETZEN, J L and ZHU, J-K (2011). Epigenetics of the epigenome. Curr. Opin. Plant Biol., 14: 113-115.

BERGER, S L; KOUZARIDES, T; SHIEKHATTAR, $\mathrm{R}$ and SHILATIFARD, A (2009). An operational definition of epigenetics. Genes Dev., 23: 781-783. 
BOWLER, C; BENVENUTO, G; LAFLAMME, P; MOLINO, D; PROBST, A V; TARIQ, $M$ and PASZKOWSKI, J (2004). Chromatin techniques for plant cells. Plant J., 39: 776-789. DOI:10.1111/j.1365313X.2004.02169.x.

BUCK, M J and LIEB, J D (2004). ChIPchip: considerations for the design, analysis, and application of genome-wide chromatin immunoprecipitation experiments. Genomics, 83: 349-360. DOI:10.1016/j.ygeno.2003.11.004.

CORLEY, R H V and TINKER, P B (2003). The Oil Palm. Fourth edition, Blackwell, Oxford, United Kingdom.

DESJARDINS, $\quad \mathrm{P}$ and CONKLIN, D (2010). NanoDrop microvolume quantitation of nucleic acids. J. Visualized Experiments, 45: e2565. DOI:10.3791/ 2565 (2010).

DINANT, C; HOUTSMULLER, A B and VERMEULEN, W (2008). Chromatin structure and DNA damage repair. Epigenetics \& Chromatin, 1: 9.

DING, Y; WANG, X; SU, L; ZHAI, J X; CAO, S Y; ZHANG, D F; LIU, C Y; BI, Y P; QIAN, Q; CHENG, $\mathrm{Z}$ K; CHU, C C and CAO, X F (2007). SDG714, a histone H3K9 methyltransferase, is involved in Tos17 DNA methylation and transposition in rice. Plant Cell, 19: 9-22. DOI:10.1105/tpc.106.048124.

DU, Z; LI, H; WEI, Q; ZHAO, X; WANG, C; ZHU, Q; YI, X; XU, W; LIU, X S; JIN, W and SU, Z (2013). Genome-wide analysis of histone modifications: H3K4me2, H3K4me3, H3K9ac and H3K27ac in Oryza sativa L. Japonica. Mol. Plant, 6(5): 1463-1472.

HARING, M; OFFERMAN, S; DANKER, T; HORST, I; PETERHANSEL, C and STAM, M (2007). Chromatin immunoprecipitation: Optimization, quantitative analysis and data normalization. Plant Methods, 3: 1. DOI:10.1186/1746-4811-3-11.

KAUFMANN, K; MUINO, J M; ØSTERÅS, M; FARINELLI, L; KRAJEWSKI, P and ANGENENT, G C (2010). Chromatin immunoprecipitation (ChIP) of plant transcription factors followed by sequencing (ChIP-SEQ) or hybridization to whole genome arrays (ChIP-ChIP). Nature Protocols, 5: 3.

KUSHAIRI, A; SINGH, R and ONG-ABDULLAH, M (2017). The oil palm industry in Malaysia: Thriving with transformative technologies. J. Oil Palm Res. Vol. 29(4): 431-439. DOI:http://doi.org/10-21894/ jopr.2017.0017.

LANDT, S G; MARINOV, G K; KUNDAJE, A; KHERADPOUR, P; PAULI, F; BATZOGLOU,
S; BERNSTEIN, B E; BICKEL, P; BROWN, J B; CAYTING, P; CHEN, Y; DESALVO, G; EPSTEIN, C; FISHER-AYLOR, K I; EUSKIRCHEN, G; GERSTEIN, M; GERTZ, J; HARTEMINK, A J; HOFFMAN, M M; IYER, V R; JUNG, Y L; KARMAKAR, S; KELLIS, M; KHARCHENKO, P V; LI, Q; LIU, T; LIU, X S; MA, L; MILOSAVLJEVIC, A; MYERS, R M; PARK, P J; PAZIN, M J; PERRY, M D; RAHA, D; REDDY, T E; ROZOWSKY, J; SHORESH, N; SIDOW, A; SLATTERY, M; STAMATOYANNOPOULOS, J A; TOLSTORUKOV, M Y; WHITE, K P; XI, S; FARNHAM, P J; LIEB, J D; WOLD, B J and SNYDER, M (2012). ChIP-seq guidelines and practices of the ENCODE and modENCODE consortia. Genome Res., 22: 1813-1831. DOI:10.1101/gr.136184.111.

LAURIA, M and ROSSI, V (2011). Epigenetic control of gene regulation in plants. Biochim. Biophys. Acta, 1809: 369-378. DOI:10.1016/j.bbagrm.2011.03.002.

LIN, X; TIRICHINE, L and BOWLER, C (2012). Protocol: Chromatin immunoprecipitation (ChIP) methodology to investigate histone modifications in two model diatom species. Plant Methods, 8: 48 .

LIU, E T; POTT, S and HUSS, M (2010). Q\&A: ChIPseq technologies and the study of gene regulation. BMC Biol., 8: 56.

LUCENA-AGUILAR, G; SÁNCHEZ-LÓPEZ, A M; BARBERÁN-ACEITUNO, C; CARRILLO-ÁVILA, J A; LÓPEZ-GUERRERO, J A and AGUILARQUESADA, R (2016). DNA source selection for downstream applications based on DNA quality indicators analysis. Biopreservation and Biobanking, 14(4): 264-270. DOI:10.1089/bio.2015.0064.

MOKRY, M; HATZIS, P; DE BRUIJN, E; KOSTER, J; VERSTEEG, R; SCHUIJERS, J; VAN DE WETERING, M; GURYEV, V; CLEVERS, $\mathrm{H}$ and CUPPEN, E (2010). Efficient double fragmentation ChIP-seq provides nucleotide resolution proteinDNA binding profiles. PLoS ONE, 5(11): e15092. DOI:10.1371/journal.pone.0015092.

MURPHY, D J (2014). The future of oil palm as a major global crop: Opportunities and challenges. J. Oil Palm Res. Vol. 26(1): 1-24.

ONG-ABDULLAH, M; MOKRI, A and CHIN, C M (2007). MPOB Taq-Polymerase (MTaq). MPOB Information Series No. 19. MPOB, Bangi.

ONG-ABDULLAH, M; ORDWAY, J M; JIANG, N; OOI, S-E; KOK, S-Y; SARPAN, N; AZIMI, N; HASHIM, A T; ISHAK, Z; ROSLI, S K; MALIKE, F A; BAKAR, N A A; MARJUNI, M; ABDULLAH, $\mathrm{N}$; YAAKUB, Z; AMIRUDDIN, M D; NOOKIAH, R; SINGH, R; LOW, E-T L; CHAN, K-L; AZIZI, N; 
SMITH, S W; BACHER, B; BUDIMAN, M A; VAN BRUNT, A; WISCHMEYER, C; BEIL, M; HOGAN, M; LAKEY, N; LIM, C-C; ARULANDOO, X; WONG, C-K; CHOO, C-N; WONG, W-C; KWAN, Y-Y; ALWEE, S S R S; SAMBANTHAMURTHI, R and MARTIENSSEN, R A (2015). Loss of karma transposon methylation underlies the mantled somaclonal variant of oil palm. Nature, 525: 533-537. DOI: $10.1038 /$ nature15365.

PARK, P J (2009). ChIP-seq: Advantages and challenges of a maturing technology. Nature Rev. Genet., 10: 669-680.

PFLUGER, J and WAGNER, D (2007). Histone modifications and dynamic regulation of genome accessibility in plants. Curr. Opin. Plant Biol., 10: 645-652.

RICARDI, M M; GONZÁLEZ, R M and LUSEM, N D (2010). Protocol: Fine tuning of a chromatin immunoprecipitation (ChIP) in tomato. Plant Methods, 6: 11 .

ROTHBART, S B and STRAHL, B D (2014). Interpreting the language of histone and DNA modifications. Biochim. Biophys. Acta, 1839: 627-643.

ROUDIER, F; AHMED, I; BÉRARD, C; SARAZIN, A; MARY-HUARD, T; CORTIJO, S; BOUYER, D; CAILLIEUX, E; DUVERNOIS-BERTHET, E; AL-SHIKHLEY, L; GIRAUT, L; DESPRÉS, B; DREVENSEK, S; BARNECHE, F; DĖROZIER, $S$; BRUNAUD, V; AUBOURG, S; SCHNITTGER, A; BOWLER, C; MARTIN-MAGNIETTE, M-L; ROBIN, S; CABOCHE, M and COLOT, V (2011). Integrative epigenomic mapping defines four main chromatin states in Arabidopsis. EMBO J., 30(10): 1928-1938.

SALEH, A; ALVARZ-VENEGAS, $\mathrm{R}$ and AVRAMOVA, Z (2008). An efficient chromatin immunoprecipitation (ChIP) protocol for studying histone modifications in Arabidopsis plants. Nature Protocols, 3(6): 1018-1028.

SARPAN, N; KOK, S-Y; CHAI, S-K; FITRIANTO, A; NURAZIYAN, A; ZAMZURI, I; ONG-ABDULLAH, $\mathrm{M}$ and OOI, S-E (2015). A model for predicting flower development in Elaeis guineensis Jacq. J. Oil Palm Res. Vol. 27(4): 315-325.

SCHULZE, J M; WANG, A Y and KOBOR, M S (2010). Reading Chromatin - insights from yeast into
YEATS domain structure and function. Epigenetics, 5(7): 573-577.

SINGH, R; LOW, E-T L; OOI, L C-L; ONG ABDULLAH, M; NOOKIAH, R; TING, N-C; MARJUNI, M; CHAN, P-L; ITHNIN, M; MANAF, M A A; NAGAPPAN, J; CHAN K-L; ROSLI, R; HALIM, M A; AZIZI, N; BUDIMAN, M A; LAKEY, $\mathrm{N}$; BACHER, B; VAN BRUNT, A; WANG, C; HOGAN, M; HE, D; MACDONALD, J D; SMITH, $S$ W; ORDWAY, J M; MARTIENSSEN, $\mathrm{R} A$ and SAMBANTHAMURTHI, R (2014). The oil palm VIRESCENS gene controls fruit colour and encodes a R2R3-MYB. Nature Commun., 5: 4106. DOI: 10.1038/ ncomms5106.

SINGH, R; ONG-ABDULLAH, M; LOW, E-T L; MANAF, M A A; ROSLI, R; NOOKIAH, R; OOI L C-L; OOI, S-E; CHAN, K-L; HALIM, $M$ A; AZIZI, N; NAGAPPAN, J; BACHER, B; LAKEY, N; SMITH, S W; HE, D; HOGAN, M; BUDIMAN, $\mathrm{M}$ A; LEE, E K; DESALLE, R; KUDRNA, D; GOICOECHEA, J L; WING, R A; WILSON, R K; FULTON, R S; ORDWAY, J M; MARTIENSSEN, R A and SAMBANTHAMURTHI, R (2013a). Oil palm genome sequence reveals divergence of infertile species in Old and New worlds. Nature, 500: 335339. DOI: 10.1038 / nature12309.

SINGH, R; LOW, E-T L; OOI, L C-L; ONGABDULLAH, M; TING, N-C; NAGAPPAN, J; NOOKIAH, R; AMIRUDDIN, M D; ROSLI, R; MANAF, M A A; CHAN, K-L; HALIM, M A; AZIZI, $\mathrm{N}$; LAKEY, N; SMITH, S W; BUDIMAN, M A; HOGAN, M; BACHER, B; VAN BRUNT, A; WANG, C; ORDWAY, J M; SAMBANTHAMURTHI, $\mathrm{R}$ and MARTIENSSEN, R A (2013b). The oil palm SHELL gene controls oil yield and encodes a homologue of SEEDSTICK. Nature, 500: 340-344. DOI: 10.1038/ nature12356.

WELLS, J and FARNHAM, PJ (2002). Characterizing transcription factor binding sites using formaldehyde crosslinking and immunoprecipitation. Methods, 26: 48-56.

WEST, P T; LI, Q; JI, L; EICHTEN, S R; SONG, J; VAUGHN, M W; SCHMITZ, R J and SPRINGER, N M (2014). Genomic distribution of H3K9me2 and DNA methylation in a maize genome. PLoS ONE, 9(8): e105267. DOI:10.1371/journal. pone. 0105267. 